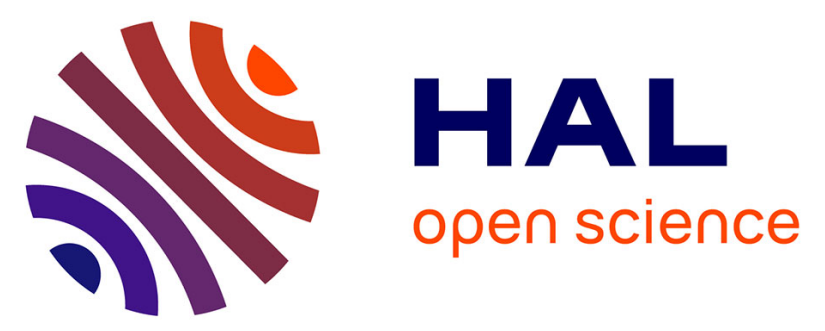

\title{
Fourteen years of evidence for positive effects of conservation agriculture and organic farming on soil life
}

Ludovic Henneron, Laetitia Bernard, Mickael Hedde, Céline Pelosi, Cécile

Villenave, Claire Chenu, Michel Bertrand, Cyril Girardin, Eric Blanchart

\section{- To cite this version:}

Ludovic Henneron, Laetitia Bernard, Mickael Hedde, Céline Pelosi, Cécile Villenave, et al.. Fourteen years of evidence for positive effects of conservation agriculture and organic farming on soil life. Agronomy for Sustainable Development, 2015, 35 (1), pp.169-181. 10.1007/s13593-014-0215-8 . hal01173289

\author{
HAL Id: hal-01173289 \\ https://hal.science/hal-01173289
}

Submitted on 27 May 2020

HAL is a multi-disciplinary open access archive for the deposit and dissemination of scientific research documents, whether they are published or not. The documents may come from teaching and research institutions in France or abroad, or from public or private research centers.
L'archive ouverte pluridisciplinaire HAL, est destinée au dépôt et à la diffusion de documents scientifiques de niveau recherche, publiés ou non, émanant des établissements d'enseignement et de recherche français ou étrangers, des laboratoires publics ou privés.

$$
\text { Copyright }
$$




\title{
Fourteen years of evidence for positive effects of conservation agriculture and organic farming on soil life
}

\author{
Ludovic Henneron • Laetitia Bernard • Mickaël Hedde • \\ Céline Pelosi • Cécile Villenave • Claire Chenu • \\ Michel Bertrand • Cyril Girardin • Eric Blanchart
}

\author{
Accepted: 21 February 2014 /Published online: 8 April 2014 \\ (C) INRA and Springer-Verlag France 2014
}

\begin{abstract}
Conventional agriculture strongly alters soil quality due to industrial practices that often have negative effects on soil life. Alternative systems such as conservation agriculture and organic farming could restore better conditions for soil organisms. Improving soil life should in turn improve soil quality and farming sustainability. Here, we have compared for the first time the long-term effects of conservation agriculture, organic farming, and conventional agriculture on major soil organisms such as microbes, nematofauna, and macrofauna. We have also analyzed functional groups. Soils were sampled at the 14-year-old experimental site of La Cage, near
\end{abstract}

\author{
L. Henneron · L. Bernard · C. Villenave • E. Blanchart $(\bowtie)$ \\ IRD, UMR Eco\&Sols (Montpellier SupAgro, CIRAD, INRA, IRD), \\ 2 place Pierre Viala, 34060 Montpellier Cedex 2, France \\ e-mail: eric.blanchart@ird.fr \\ M. Hedde $\cdot$ C. Pelosi \\ INRA, UR251 PESSAC, 78026 Versailles Cedex, France \\ C. Villenave \\ ELISOL Environnement, Campus la Gaillarde, 2 place Viala, \\ 34060 Montpellier Cedex 2, France \\ C. Chenu \\ AgroParisTech, UMR BioEMCo (Univ. Paris 6, Univ. Paris 12, \\ AgroParisTech, ENS, CNRS, INRA, IRD), \\ 78850 Thiverval-Grignon, France \\ M. Bertrand \\ INRA, UMR Agronomie INRA, AgroParisTech, \\ 78850 Thiverval-Grignon, France \\ M. Bertrand \\ AgroParisTech, UMR Agronomie INRA, AgroParisTech, \\ 78850 Thiverval-Grignon, France \\ C. Girardin \\ INRA, UMR BioEMCo (Univ. Paris 6, Univ. Paris 12, \\ AgroParisTech, ENS, CNRS, INRA, IRD), \\ 78850 Thiverval-Grignon, France
}

Versailles, France. The microbial community was analyzed using molecular biology techniques. Nematofauna and macrofauna were analyzed and classified into functional groups. Our results show that both conservation and organic systems increased the abundance and biomass of all soil organisms, except predaceous nematodes. For example, macrofauna increased from 100 to $2,500 \%$, nematodes from 100 to $700 \%$, and microorganisms from 30 to $70 \%$. Conservation agriculture showed a higher overall improvement than organic farming. Conservation agriculture increased the number of many organisms such as bacteria, fungi, anecic earthworms, and phytophagous and rhizophagous arthropods. Organic farming improved mainly the bacterial pathway of the soil food web and endogeic and anecic earthworms. Overall, our study shows that long-term, no-tillage, and cover crops are better for soil biota than periodic legume green manures, pesticides, and mineral fertilizers.

Keywords Soil biodiversity · Functional groups $\cdot$ Soil food web · Soil functioning $\cdot$ Soil quality $\cdot$ Land management . Agricultural sustainability $\cdot$ Agroecosystems $\cdot$ Agroecology

\section{Introduction}

The green revolution has successfully increased crop yields by adopting intensive production practices, including genetic crop improvement, the use of massive chemical inputs (e.g., fertilizers and pesticides), and intensive tillage. However, this high input agricultural management has generated many negative environmental impacts, such as soil erosion, greenhouse gas emission, groundwater pollution, eutrophication of lakes and rivers, and biodiversity loss (Tilman et al. 2002). Whereas the food demand is still increasing, these environmental issues are nowadays of major concerns for human societies, as well as the dependency of this agricultural model on fossil energy. 
Therefore, modern agriculture now faces the challenge to develop sustainable systems that pursue production intensification while greatly mitigating their environmental impacts. One solution to overcome this dilemma is the ecological intensification of the production (Bommarco et al. 2012). This new agricultural paradigm is based on the substitution of the use of artificial inputs by an improved management of ecological processes in order to rely more efficiently on agroecosystem self-regulation (Altieri 1999).

Soil is an essential component of agroecosystems and it supports many ecosystem services such as food provisioning, climate regulation, erosion regulation, etc. Soil biota is an essential driver of soil functioning since soil organisms are involved in major soil functions, i.e., nutrient cycling, soil structure maintenance, carbon transformations, and biological population regulation (Altieri 1999; Kibblewhite et al. 2008). Many ecosystem services are directly dependent on these soil functions (Kibblewhite et al. 2008). Soil microorganisms, nematofauna, and macrofauna are major actors of the soil food web and soil functioning in agroecosystems (de Vries et al. 2013). Microorganisms are the main organic matter decomposers, and they drive the major biogeochemical cycles in soil. However, soil fauna-microorganism interactions are of primary importance in controlling soil processes. Trophic interactions between microorganisms and microbivorous nematodes in the soil micro-food web play a crucial role in microbial population regulation and nutrient cycling (Fig. 1, photograph of a bacteria-feeding nematode). Saprophagous (litter transformers) or geophagous (processing soil organic matter) soil invertebrates are also strong drivers of soil microbial activity (Fig. 1, photograph of an anecic earthworm). Moreover, other groups of soil fauna have more direct interactions with the plant community: these effects can be either harmful for crop pests (some herbivores and rhizophagous) or beneficial as biotic regulators of weeds (granivores and frugivores) and crop pests (top predators).

The agricultural intensification of the green revolution paradigm has often been shown to have important negative impacts on soil biota (Postma-Blaauw et al. 2010). This is related to many different agricultural practices, including heavy tillage, detrimental crop residue management, lack of organic amendments, and application of pesticides (Kibblewhite et al. 2008). However, alternative crop management systems have emerged such as conservation agriculture, based on minimum tillage, permanent living, or dead organic soil cover and rotations, and organic farming, based on the exclusion of synthetic inputs. Therefore, alternative farming systems could potentially restore more favorable conditions for soil biota than conventional farming systems which have been demonstrated in many studies (e.g., House and Brust 1989; Vandermeer 1995). However, the extent of the enhancement effect of alternative cropping systems on soil biota remains unclear, and the results of the existing studies are often variable and sometimes contradictory (Wardle 1995; Bengtsson et al. 2005). Further, the sensitivity to cropping management could be very different between soil organism groups (Postma-Blaauw et al. 2010). Moreover, there is a lack of studies comparing the enhancement effect of organic and conservation versus conventional farming systems on soil biota at multiple trophic levels and functional groups.

The aim of this study was to compare different groups of soil biota, i.e., soil microorganisms, nematofauna, and macrofauna, from taxonomic and functional points of view, in three contrasted long-term (14 years) cropping systems, conventional, organic, and conservation agriculture, in northern France. We hypothesized that (i) the alternative farming systems improve the overall soil biota abundance and/or biomass compared to the conventional system, and (ii) the conservation and the organic systems do not favor the improvement of the same taxa or functional groups due to the very different practices implemented in these two systems.

\section{Materials and methods}

\subsection{Site and soil characteristics}

The study was conducted on the experimental station of $\mathrm{La}$ Cage near Versailles, France $\left(48^{\circ} 48^{\prime} \mathrm{N}, 2^{\circ} 08^{\prime}\right.$ E, elevation 110 masl) (Fig. 1). The experimental site is an agronomic trial established in 1997 by INRA in order to assess the agronomic, economic, and environmental performances of contrasted cropping systems representative of the Paris Basin cereal production, characterized by short rotations, absence of organic amendment, and important production of winter wheat. Before the trial setup, the site was under conventional agriculture management. The climate is oceanic temperate, with a mean annual temperature of $11.1{ }^{\circ} \mathrm{C}$ and a mean annual rainfall of $660 \mathrm{~mm}$. The soil is a deep Luvisol (FAO soil classification) developed on loess with a silt loam type texture.

\subsection{Experimental design}

The trial is arranged in a randomized complete block design and is divided into two blocks, each including one 1-ha plot replicate of each system. Each replicate is divided into two subplots with a winter wheat crop each year on one of these. Despite the limited numbers of treatment replicates available $(n=2)$, this trial is worthwhile as it is a long-term trial ( 14 years of cropping systems differentiation) and the plot size is realistic $(0.5 \mathrm{ha})$, managed under real agricultural practices unlike many studies which use small or very small experimental plots (Blanchart et al. 2006; Birkhofer et al. 2008a; Postma-Blaauw et al. 2010; Wardle et al. 2001). This trial has already been used to evaluate cropping systems (Pelosi et al. 2009a; Debaeke et al. 2009). 

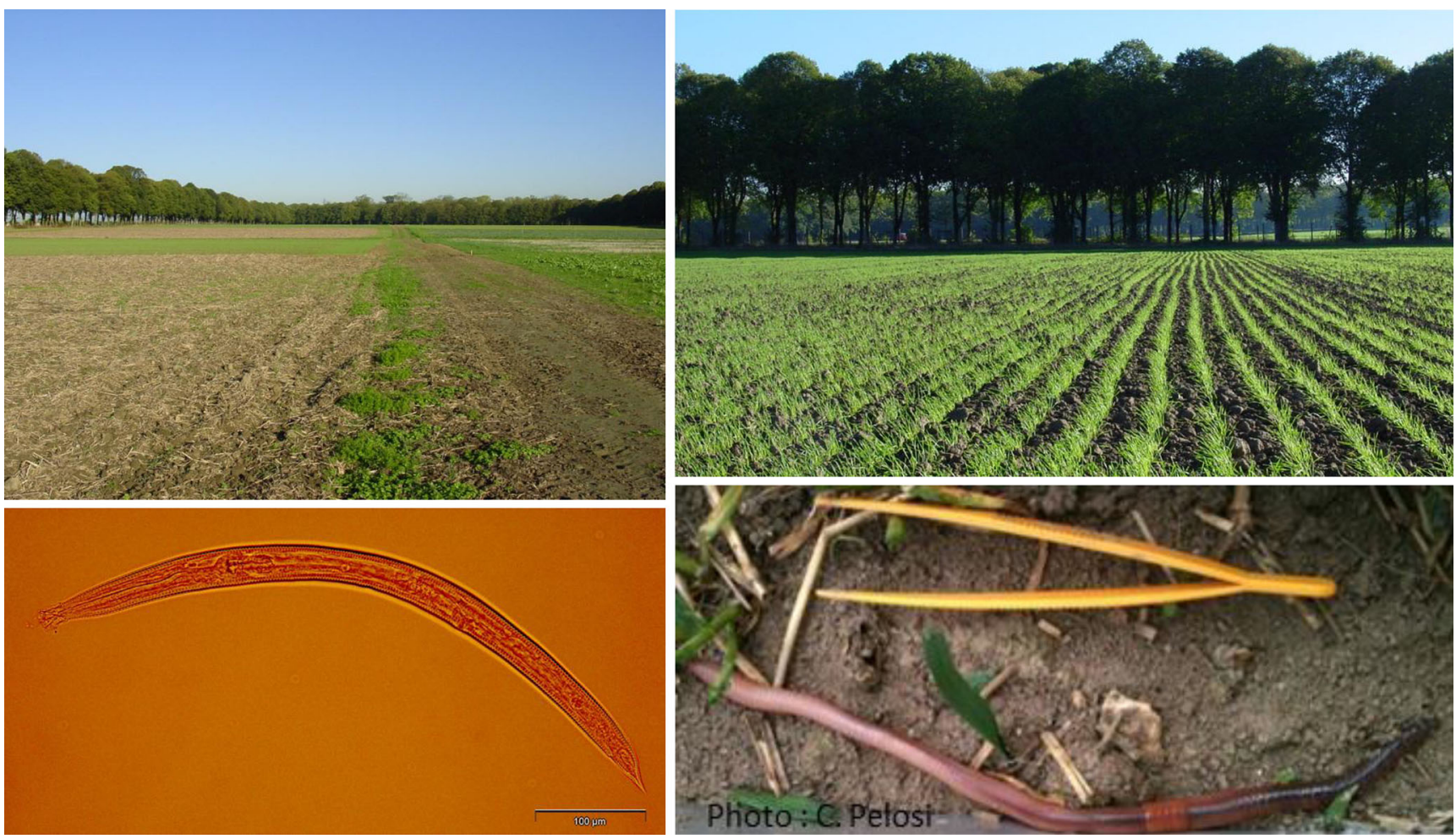

Fig. 1 Photographs of the site of La Cage near Versailles (upper left: general view of the site; upper right: organic system, credit M. Bertrand). Lower left: photograph of Acrobeles sp. (Cephalobidae), a bacteria-

Three cropping systems were studied: a conventional system, an organic system, and a direct seeding living mulchbased system classified as a conservation system. Their management differs mainly in soil tillage, cover crop and green manure use, pesticide and mineral fertilizer applications, and rotations (Table 1). In the conventional system, pesticide and mineral fertilizer applications were adjusted so as to maximize crop biomass production and soil was plowed three times every 4 years. The organic system was conducted following the rules of the "AB France" label with no synthetic pesticide and fertilizer use. Moreover, no organic amendment was applied due to the absence of livestock farming in the Paris Basin agricultural production, but legume green manure was used for $\mathrm{N}$ supply. Weed management was based on soil tillage, including plowing three times every 4 years, weed smothering by crop density, and gaps in crop sowing dates. In case of overrun by weeds, 2 years of alfalfa was included to the rotation. The conservation system was based on no-tillage and grass cover crop use. Pesticides were used only when the economic damage threshold was exceeded. Crop residues were not exported for all the cropping systems. Crop management in the three systems during the sampling year is shown in Table 1. On average over the last 5 years, the wheat yield was 9.6, 6.2, and $6.8 \mathrm{t} \mathrm{ha}^{-1}$ in the conventional, organic, and conservation systems, respectively. feeding nematode (credit C. Villenave). Lower right: photograph of Lumbricus terrestris (Lumbricidae), a common anecic species (credit C. Pelosi)

\subsection{Soil sampling and chemical analysis}

Soil was sampled in the six plots ( 2 blocks $\times 3$ systems) under winter wheat crop in March 2011. In each subplot, four composite soil samples were collected, each obtained from 12 soil cores $(0-10 \mathrm{~cm}$ depth, $4 \mathrm{~cm} \varnothing)$ randomly dug out in a 4- $\mathrm{m}^{2}$ sample area. Each sample point was separated of at least $20 \mathrm{~m}$ from each other and was located at least $10 \mathrm{~m}$ away from the field margins in order to avoid edge effect. Soil samples were then sieved $(10 \mathrm{~mm})$ and used for chemical, microbial, and nematofauna analyses. After air drying and sieving $(2 \mathrm{~mm})$, total organic carbon $\left(C_{\text {org }}\right)$ and total nitrogen $\left(N_{\text {tot }}\right)$ contents were measured by dry combustion using an elemental analyzer CHN Fisons/Erba NA 2000 (Milan, Italy). Soil $\mathrm{pH}$ was measured in a soil suspension with demineralized water $(1: 2.5 w / w)$ (Table 2).

\subsection{Microbial analysis}

Microbial communities were analyzed using molecular techniques. A quantitative DNA-RNA co-extraction method was used to assess the abundance of the total and active part of microbial communities. Prior to the nucleic acid extraction, $30 \mathrm{~g}$ of soil sample was homogenized by crushing in a mortar in the presence of liquid nitrogen. The co-extraction was 
Table 1 Crop management in the three cropping systems during the sampling year (July 2010-March 2011)

\begin{tabular}{|c|c|c|c|c|}
\hline \multicolumn{2}{|l|}{ Cropping system } & Conventional & Organic & Conservation \\
\hline \multicolumn{2}{|l|}{ Rotation } & $\begin{array}{l}\text { Wheat-pea-wheat- } \\
\text { oilseed rape }\end{array}$ & $\begin{array}{l}\text { Wheat-pea-wheat-oilseed } \\
\text { rape-(alfalfa-alfalfa) }{ }^{\mathrm{a}}\end{array}$ & $\begin{array}{l}\text { Wheat-pea- } \\
\text { wheat-maize }\end{array}$ \\
\hline \multicolumn{2}{|l|}{ Preceding crop } & Pea & Alfalfa & Wheat \\
\hline \multicolumn{2}{|l|}{ Sampling year crop } & Wheat & Wheat & Wheat \\
\hline \multicolumn{2}{|l|}{ Permanent plant cover } & - & - & Red fescue \\
\hline \multirow[t]{3}{*}{ Soil tillage (number of passages) } & $\begin{array}{l}\text { Plowing ( } 30 \mathrm{~cm} \text { depth) } \\
\text { Last operation date }\end{array}$ & $\begin{array}{l}0 \\
\text { November } 2009\end{array}$ & $\begin{array}{l}1 \\
\text { October } 2010\end{array}$ & $\begin{array}{l}0 \\
\text { Before } 1997\end{array}$ \\
\hline & $\begin{array}{l}\text { Stubble plowing } \\
(10 \mathrm{~cm} \text { depth }) \\
\text { Last operation date }\end{array}$ & $\begin{array}{l}3 \\
\text { October } 2010\end{array}$ & $\begin{array}{l}0 \\
\text { March } 2009\end{array}$ & $\begin{array}{l}0 \\
\text { Before } 1997\end{array}$ \\
\hline & Rolling & 1 & 0 & 0 \\
\hline \multirow[t]{4}{*}{ Fertilization $\left(\mathrm{kg} \mathrm{ha}^{-1}\right)$} & $\mathrm{N}$ & 450 & 0 & 0 \\
\hline & $\mathrm{P}_{2} \mathrm{O}_{5}$ & 132 & 0 & 0 \\
\hline & $\mathrm{K}_{2} \mathrm{O}$ & 144 & 0 & 0 \\
\hline & Organic amendment & 0 & 0 & 0 \\
\hline \multirow[t]{4}{*}{ Pesticides (number of treatments) } & $\begin{array}{l}\text { Herbicide }^{\mathrm{b}} \\
\text { Last application date }\end{array}$ & $\begin{array}{l}3 \\
\text { October } 2010\end{array}$ & $\begin{array}{l}0 \\
\text { Before } 1997\end{array}$ & $\begin{array}{l}2 \\
\text { February } 2011\end{array}$ \\
\hline & $\begin{array}{l}\text { Fungicide }^{\mathrm{c}} \\
\text { Last application date }\end{array}$ & $\begin{array}{l}0 \\
\text { June } 2010\end{array}$ & $\begin{array}{l}0 \\
\text { Before } 1997\end{array}$ & $\begin{array}{l}0 \\
\text { June } 2008\end{array}$ \\
\hline & Molluscicide $^{\mathrm{d}}$ & 1 & 0 & 1 \\
\hline & $\begin{array}{l}\text { Insecticide } \mathrm{e}^{\mathrm{e}} \\
\text { Last application date }\end{array}$ & $\begin{array}{l}0 \\
\text { June } 2010\end{array}$ & $\begin{array}{l}0 \\
\text { July } 1997\end{array}$ & $\begin{array}{l}0 \\
\text { April } 2002\end{array}$ \\
\hline Liming & Last application date & - & - & September 2007 \\
\hline
\end{tabular}

${ }^{a}$ Two years of alfalfa is included to the rotation in case of overrun by weeds

${ }^{\mathrm{b}}$ In conventional: glyphosate (September $2010-1,350 \mathrm{~g} \mathrm{ha}^{-1}$ ), diflufenicanil (October 2010-13.2 $\mathrm{g} \mathrm{ha}^{-1}$ ), isoproturon (October 2010-110 $\mathrm{g}$ ha ${ }^{-1}$ ), iodosulfuron-methyl-sodium (March 2011-1.87 $\mathrm{g} \mathrm{ha}^{-1}$ ), mesosulfuron-methyl (March 2011-1.87 $\mathrm{g} \mathrm{ha}^{-1}$ ), and mefenpyr-dimethyl (March 2011$5.62 \mathrm{~g} \mathrm{ha}^{-1}$ ). In conservation: cycloxydime (September 2010-120 $\mathrm{g} \mathrm{ha}^{-1}$ ) and isoproturon (February 2011-1,200 $\mathrm{g} \mathrm{ha}^{-1}$ )

${ }^{\mathrm{c}}$ In conventional: azoxystrobin (June $2010-125 \mathrm{~g} \mathrm{ha}^{-1}$ ). In conservation: azoxystrobin (June 2008 - $125 \mathrm{~g} \mathrm{ha}^{-1}$ ), fenpropimorph (June 2008 $150 \mathrm{~g} \mathrm{ha}^{-1}$ ), and epoxiconazole (June 2008-50.4 $\mathrm{g} \mathrm{ha}^{-1}$ )

${ }^{\mathrm{d}}$ In conventional: methiocarb (October $2010-120 \mathrm{~g} \mathrm{ha}^{-1}$ ). In conservation: metaldehyde (October 2010-150 $\mathrm{g} \mathrm{ha}^{-1}$ )

${ }^{\mathrm{e}}$ In conventional: pirimicarb (June 2010—125 $\mathrm{g} \mathrm{ha}^{-1}$ ) and cyhalothrin (June $2010-6.25 \mathrm{~g} \mathrm{ha}^{-1}$ ). In conservation: unknown

Table 2 Soil chemical and microbial parameters and nematode indices in the three cropping systems (mean \pm standard error, $n=8$ )

\begin{tabular}{|c|c|c|c|c|}
\hline & Conventional & Organic & Conservation & Cropping system effect \\
\hline$C_{\text {org }}\left(\mathrm{g} \mathrm{kg}^{-1}\right.$ soil $)$ & $9.36 \pm 0.24 b$ & $9.13 \pm 0.13 b$ & $13.59 \pm 0.24 \mathrm{a}$ & $* * *$ \\
\hline$N_{\text {tot }}\left(\mathrm{g} \mathrm{kg}^{-1}\right.$ soil $)$ & $1.16 \pm 0.03 \mathrm{~b}$ & $1.12 \pm 0.02 \mathrm{~b}$ & $1.42 \pm 0.02 \mathrm{a}$ & $* * *$ \\
\hline$C / N$ ratio & $8.07 \pm 0.20 \mathrm{~b}$ & $8.17 \pm 0.15 b$ & $9.56 \pm 0.19 \mathrm{a}$ & $* * *$ \\
\hline $\mathrm{pH}_{\text {water }}$ & $6.61 \pm 0.08 \mathrm{~b}$ & $7.00 \pm 0.09 \mathrm{a}$ & $6.26 \pm 0.08 \mathrm{c}$ & $* * *$ \\
\hline DNA ( $\mu \mathrm{g} \mathrm{g}^{-1}$ soil) & $20.11 \pm 1.38 \mathrm{c}$ & $25.90 \pm 1.73 \mathrm{~b}$ & $34.21 \pm 0.99 \mathrm{a}$ & $* * *$ \\
\hline DNA $/ C_{\text {org }}$ ratio (mg DNA g ${ }^{-1} C_{\text {org }}$ ) & $2.15 \pm 0.14 \mathrm{~b}$ & $2.84 \pm 0.20 \mathrm{a}$ & $2.52 \pm 0.09 \mathrm{ab}$ & * \\
\hline RNA ( $\mu \mathrm{g} \mathrm{g}^{-1}$ soil) & $1.25 \pm 0.17$ & $1.41 \pm 0.13$ & $1.13 \pm 0.07$ & ns \\
\hline RNA/DNA ratio & $0.066 \pm 0.012 \mathrm{a}$ & $0.055 \pm 0.004 \mathrm{ab}$ & $0.033 \pm 0.002 \mathrm{~b}$ & $* *$ \\
\hline Fungi/bacteria ratio & $0.030 \pm 0.001$ & $0.026 \pm 0.001$ & $0.032 \pm 0.003$ & ns \\
\hline Maturity index (MI) & $2.37 \pm 0.08 \mathrm{a}$ & $1.65 \pm 0.06 \mathrm{c}$ & $2.07 \pm 0.09 \mathrm{~b}$ & $* * *$ \\
\hline Enrichment index (EI) & $68.5 \pm 1.9 \mathrm{~b}$ & $84.6 \pm 3.5 \mathrm{a}$ & $69.7 \pm 3.6 b$ & $* * *$ \\
\hline Structure index (SI) & $58.0 \pm 3.4 \mathrm{a}$ & $34.5 \pm 4.6 \mathrm{~b}$ & $45.7 \pm 6.1 \mathrm{ab}$ & $* *$ \\
\hline Fungivore/bacterivore ratio & $0.76 \pm 0.14 \mathrm{a}$ & $0.13 \pm 0.03 \mathrm{~b}$ & $0.27 \pm 0.04 \mathrm{~b}$ & $* * *$ \\
\hline
\end{tabular}

Different letters indicate significant Tukey's HSD differences between cropping systems at $\alpha=5 \%$.

${ }^{* * *} p<0.001,{ }^{* *} p<0.01, * p<0.05,{ }^{\mathrm{ns}} p>0.05$ 
realized on a 250-mg subsample by coupling the "FastDNA SPIN"M kit for soil" and the "RNaid" kit" (MP Biomedicals, Santa Ana, CA, USA). The initial protocol of the FastDNA kit has been modified as follows: before the procedure began, all solutions and glassware were treated with diethylpyrocarbonate (DEPC) to ensure that they were RNase free and only certified RNase- and DNase-free plastic tubes were used. Subsamples of soil were placed in Lysing Matrix E tubes and frozen at $-80{ }^{\circ} \mathrm{C}$ overnight. At the beginning of the procedure, soil was first immerged in the lysis buffer and two grinding cycles were performed instead of one. Each centrifugation step was performed at $4{ }^{\circ} \mathrm{C}$ and tubes were placed on ice while waiting for the next step of the procedure. RNA was recovered in the wash solution after the binding of DNA on the selective matrix, and increasing the DNA binding time from 5 to $12 \mathrm{~min}$ avoided DNA contamination into the washing solution containing RNA. The RNA was concentrated by isopropanol precipitation ( $1 \mathrm{vol}$ isopropanol; $0.1 \mathrm{vol}$ acetate sodium $3 \mathrm{M} \mathrm{pH} 4$ ) at $-20{ }^{\circ} \mathrm{C}$ during $1.5 \mathrm{~h}$ and then purified following the protocol of the RNaid ${ }^{\mathrm{TM}} \mathrm{Kit}$ (MP Biomedicals). DNA and RNA were finally eluted with $150 \mu \mathrm{L}$ DES and $60 \mu \mathrm{L}$ RNase-free water, respectively. DNA and RNA were quantified by fluorometry using the "Quan-iT ${ }^{\mathrm{TM}}$ PicoGreen ${ }^{\circledR}$ dsDNA Assay Kit" and the "Quan-iT ${ }^{\mathrm{TM}}$ RiboGreen ${ }^{\circledR} \mathrm{RNA}$ Assay Kit" (Invitrogen, Carlsbad, CA, USA), respectively.

Fungi and bacteria as well as the composition of the bacterial community were also studied. The diversity of bacteria in soil is tremendous, and analyzing it to infer functional implications is very challenging. Philippot et al. (2010) argued that high bacterial taxonomic ranks have an ecological coherence. Therefore, the abundance of fungi and bacteria, Proteobacteria ( $\alpha, \beta$, and $\gamma$ classes), Acidobacteria, Actinobacteria, Bacteroidetes, Firmicutes, and Gemmatimonadetes bacterial phyla, was assessed by quantitative real-time PCR using taxa-specific 16S and 18S rDNA primers previously described (Fierer et al. 2005). Primer sequences, references, and amplification conditions are given in Table 3. Amplification reactions were conducted in $10 \mu \mathrm{L}$ final volume containing $5 \mu \mathrm{L}$ of "Absolute QPCR SYBR Green Mix" (Thermo Scientific, Waltham, MA, USA), $0.5 \mu \mathrm{L}$ of T4gp32 (MP Biomedicals, Santa Ana, CA, USA), 10 to $20 \mu \mathrm{M}$ of each primer, and $10 \mathrm{ng}$ of DNA template and were followed by a CFX96 ${ }^{\mathrm{TM}}$ real-time PCR detection system (BioRad, Hercules, CA, USA).

\subsection{Nematofauna analysis}

Nematodes were extracted from a 165-g mean of wet soil using the Oostenbrink elutriation technique (ISO 23611-4 2007). After being counted, nematodes were fixed in a $4 \%$ formaldehyde solution and a representative subsample was mounted on glass slides for identification at high magnification $(\times 400)$. For each sample, a mean of 155 nematodes was identified to the family or genus level. Nematode taxa were then assigned to six trophic groups modified from Yeates et al. (1993): bacterivores, fungivores, omnivores, carnivores, obligate phytophagous, and facultative phytophagous. The maturity index (MI) as defined by Bongers (1990) was calculated as the weighted average of colonizer-persister $(c-p)$ values for each taxon according to the $1-5 c-p$ scale defined by Bongers and Bongers (1998). Nematodes were also assigned to functional guilds according to trophic groups and colonizer-persister classes. For example, bacterial feeders with a $c-p$ value of 2 were placed in functional guild $\mathrm{Ba} 2$, and fungal feeders with a $c-p$ class of 3 were placed in functional guild Fu3. Two nematode ecological indices were further calculated after Ferris et al. (2001): the enrichment index (EI) and the structure index (SI). EI is meant to assess food web response to availability of resources; SI indicates whether the soil community is basal (typical of disturbed systems) or structured (typical of more stable systems).

\subsection{Macrofauna sampling and analysis}

As for the soil sampling, macrofauna was sampled in the six subplots under winter wheat crop in March 2011. On each subplot, the sampling was realized on five $4-\mathrm{m}^{2}$ zones located at least $20 \mathrm{~m}$ from each other and at least $10 \mathrm{~m}$ away from the field margins. A sampling method combining chemical extraction (to sample anecic earthworms) and hand-sorting was used (Bouché and Gardner, 1984; Pelosi et al., 2009b). First, 3.2 L of an expellant solution of allyl isothiocyanate (AITC, $0.1 \mathrm{~g} \mathrm{~L}^{-1}$ ) was applied twice (at 10-min intervals) to the soil within a 40 -cm $\times 40$-cm metal frame. After recovering organisms that emerged to the soil surface during $20 \mathrm{~min}$, a $40 \times 40 \times$ 20-cm-deep soil monolith was excavated, and all macroinvertebrates were extracted by hand-sorting. They were counted and identified (at species level for earthworms and ground beetles). Additionally, earthworms were weighed. Macroinvertebrates were then gathered according to their trophic behavior into seven trophic groups, i.e., geophagous, detritivores, herbivores (aerial plant material feeders), rhizophagous, granivores, frugivores, and predators (BETSI database, INRA, unpublished), for determining the affinity percentage of each taxa for each diet. Earthworms were also grouped according to their ecological category: anecic, endogeic, and epigeic.

\subsection{Biological index computation}

The response of the abundance of taxonomic and functional groups to alternative (organic or conservation) versus conventional cropping systems was evaluated by calculating the index $V$ adapted from Wardle (1995) as follows: $V=\frac{2 M_{\mathrm{AC}}}{M_{\mathrm{AC}}+M_{\mathrm{CC}}}-1$, with $M_{\mathrm{AC}}$ and $M_{\mathrm{CC}}=$ abundance of 
Table 3 qPCR primers and amplification conditions

\begin{tabular}{|c|c|c|c|c|}
\hline Phyla & Primer pairs & Sequences $\left(5^{\prime}-3-\right)$ & Final concentration $(\mu \mathrm{M})$ & Program \\
\hline \multirow[t]{2}{*}{ Bacteria $^{\mathrm{a}}$} & $341 \mathrm{~F}$ & CCT ACG GGA GGC AGC AG & 1 & \multirow[t]{2}{*}{$\mathrm{A}$} \\
\hline & $534 \mathrm{R}$ & ATT ACC GCG GCT GCT GGC A & 1 & \\
\hline \multirow[t]{2}{*}{ Acidobacteria ${ }^{\mathrm{b}}$} & Acid31 & GAT CCT GGC TCA GAA TC & 1 & \multirow[t]{2}{*}{$\mathrm{B}$} \\
\hline & Eub518 & ATT ACC GCG GCT GCT GG & 1 & \\
\hline \multirow[t]{2}{*}{ Actinobacteria $^{\mathrm{b}}$} & Actino 235 & CGC GGC CTA TCA GCT TGT TG & 1 & \multirow[t]{2}{*}{ A } \\
\hline & Eub518 & ATT ACC GCG GCT GCT GG & 1 & \\
\hline \multirow[t]{2}{*}{$\alpha$-Proteobacteria ${ }^{\mathrm{b}}$} & Eub338 & ACT CCT ACG GGA GGC AGC AG & 1 & \multirow[t]{2}{*}{$\mathrm{A}$} \\
\hline & Alfa685 & TCT ACG RAT TTC ACC YC TAC & 2 & \\
\hline \multirow[t]{2}{*}{$\beta$-Proteobacteria ${ }^{\mathrm{b}}$} & Eub338 & ACT CCT ACG GGA GGC AGC AG & 1 & \multirow[t]{2}{*}{$\mathrm{B}$} \\
\hline & Bet680 & TCA CTG CTA CAC GYG & 2 & \\
\hline \multirow[t]{2}{*}{$\gamma$-Proteobacteria ${ }^{\mathrm{c}}$} & Gam395F & CMA TGC CGC CGC GTG TGT GAA & 2 & \multirow[t]{2}{*}{$\mathrm{B}$} \\
\hline & Gam871R & ACT CCC CAG GCG GTC DAC TTA & 2 & \\
\hline \multirow[t]{2}{*}{ Bacteroidetes $^{\mathrm{a}}$} & Cfb319 & GTA CTG AGA CAC GGA CCA & 1 & \multirow[t]{2}{*}{ A } \\
\hline & Eub518 & ATT ACC GCG GCT GCT GG & 1 & \\
\hline \multirow[t]{2}{*}{ Firmicutes $^{\mathrm{a}}$} & $\operatorname{Lgc} 353$ & GCA GTA GGG AAT CTT CCG & 1 & \multirow[t]{2}{*}{$\mathrm{B}$} \\
\hline & Eub518 & ATT ACC GCG GCT GCT GG & 1 & \\
\hline \multirow[t]{2}{*}{ Gemmatimonadetes $^{\mathrm{a}}$} & Gem440 & TTC CGR KTG TAA ACC ACT GT & 2 & \multirow[t]{2}{*}{$\mathrm{A}$} \\
\hline & Eub518 & ATT ACC GCG GCT GCT GG & 1 & \\
\hline \multirow[t]{2}{*}{ Fungi $^{\mathrm{d}}$} & FR1 & AIC CAT TCA ATC GGT AIT & 1.25 & \multirow[t]{2}{*}{$\mathrm{C}$} \\
\hline & FF390 & CGA TAA CGA ACG AGA CCT & 1.25 & \\
\hline
\end{tabular}

Each phylogenetic group (first column) was quantified by qPCR technique using a pair of primers (forward and reverse) described in the literature cited below the table. Names and nucleic acid sequences of primers are given in the second and the third columns. The fourth column indicates the final concentration of each primer in the PCR reaction mix, while the last column refers to the amplification program followed by the thermocycler for each primer pair. Each program begins by a first denaturation step of $15 \mathrm{~min}$ at $95^{\circ} \mathrm{C}$ to denature the whole genomic DNA templates. This step is followed by a 15-s denaturation period, a 30-s primers annealing period, and an 80-s DNA elongation period, repeated over 35 cycles

$A\left(95^{\circ} \mathrm{C}-15 \mathrm{~min}\right) 1 \mathrm{cycle},\left(95^{\circ} \mathrm{C}-15 \mathrm{~s}, 60^{\circ} \mathrm{C}-30 \mathrm{~s}, 80^{\circ} \mathrm{C}-30 \mathrm{~s}\right) 35$ cycles; $B\left(95^{\circ} \mathrm{C}-15 \mathrm{~min}\right) 1$ cycle, $\left(95^{\circ} \mathrm{C}-15 \mathrm{~s}, 55^{\circ} \mathrm{C}-30 \mathrm{~s}, 80^{\circ} \mathrm{C}-30 \mathrm{~s}\right) 35 \mathrm{cycles} ; \mathrm{C}$ $\left(95^{\circ} \mathrm{C}-15 \mathrm{~min}\right) 1 \mathrm{cycle},\left(95^{\circ} \mathrm{C}-15 \mathrm{~s}, 50^{\circ} \mathrm{C}-30 \mathrm{~s}, 80^{\circ} \mathrm{C}-30 \mathrm{~s}\right) 35$ cycles (annealing temperatures are written in italics as they are the only parameter that varies depending on primer pairs)

${ }^{\text {a }}$ Philippot et al. (2009)

${ }^{\mathrm{b}}$ Fierer et al. (2005)

${ }^{\mathrm{c}}$ Mühling et al. (2008)

${ }^{\mathrm{d}}$ Vainio and Hantula (2000)

organisms under alternative (organic or conservation) and conventional cropping system, respectively. The index $V$ ranged from -1 (maximum inhibition: organisms occur only in conventional cropping system) to +1 (maximum stimulation: organisms occur only in alternative cropping system). Zero represents equal densities.

\subsection{Statistical analysis}

Because the numbers of treatment replicates available in this trial were too low $(n=2)$, we chose to consider each sample point as a replicate, though this approach could have induced some bias because of pseudoreplications. We are however quite confident that our sampling design allowed us to use this approach for several reasons: (i) sample points within a plot were far enough from each other $(20 \mathrm{~m})$ to ensure replicate independence, and (ii) the possibility that the sample plots were affected by confounding factors due to limited randomization cannot be excluded but was limited as the trial was evenly affected by the same management before the trial setup, the preexisting topographic and pedologic gradients were controlled by blocking, and a preliminary assessment of the trial spatial heterogeneity was found very low withinblock soil heterogeneity.

Statistical analyses were performed using $\mathrm{R}$ version 2.15 .1 software, and statistical tests used were realized with $\alpha=5 \%$. The effect of cropping systems on studied variables was assessed using analysis of variance (ANOVA) followed by a Tukey's honest significant difference (HSD) post hoc test. A linear mixed model with "cropping system" as a fixed factor and "block" as a random factor was adopted ("Ime4" package). The normal distribution and the homoscedasticity of variance of the model residuals were checked using ShapiroWilk and Bartlett test, respectively. In case of unconformity, data were transformed by $f(x)=\log _{10}(x+1)$ or $f(x)=\sqrt{ }(x)$.

A principal component analysis (PCA) was performed on a variables $\times$ samples table using XISTAT (Addinsoft). Molecular biomass (DNA and RNA), densities of taxonomic and functional groups (macrofauna, nematofauna, and microorganisms) and physicochemical parameters (pH, $C_{\text {org }}, N_{\text {tot }}, C /$ 
$N)$ were considered as active quantitative variables. Gravity centers were calculated for samples depending on agricultural systems and replication blocs.

\section{Results and discussion}

\subsection{Overall soil biota response to cropping systems}

Many studies have assessed the effect of agricultural systems on specific soil taxonomic groups. Our study is comparing three major agricultural systems for a wide range of taxonomic and functional groups. The cropping systems investigated here presented important differences of abundance and/or biomass for almost all soil organism groups. Both alternative cropping systems (conservation and organic) resulted in an overall increase of soil biota compared to the conventional system (Figs. 2, 3, 4, and 5 and Table 2). The mean abundance of each taxonomic and functional groups was higher in alternative systems than in the conventional one, except for predaceous (5.2 and 22.8 individuals (ind.) $100 \mathrm{~g}^{-1}$ soil in the organic and conventional systems, respectively) and fungal feeder (32.3 and 46.4 ind. $100 \mathrm{~g}^{-1}$ soil, respectively) nematodes, and Diplopoda (10 and 14 ind. $\mathrm{m}^{-2}$, respectively) in the organic system (Fig. 2). Some other groups were not impacted by cropping systems, e.g., predaceous nematodes and endogeic earthworms in the conservation system (same densities in conservation and conventional systems).

Such an improvement of soil biota by alternative farming systems has been observed previously for both conservation agriculture (e.g., Hendrix et al. 1986; Marasas et al. 2001; Blanchart et al. 2006; Helgason et al. 2009; DuPont et al. 2009) and organic farming (e.g., Mäder et al. 2002; Hole et al. 2005; Birkhofer et al. 2008a). Our study showed that for many biological groups, this increase effect was more important for the conservation agriculture system than for the organic farming system: most nematode guilds, Insecta larvae, Gastropoda, Araneae, and most functional groups of macrofauna except geophagous invertebrates (Figs. 2, 3, 4, and 5). A large diversity of agricultural practices could be involved behind each of these farming systems depending on local context. Here, a long-term recovery of soil biota in the conservation system was probably mainly induced by the absence of tillage associated with the presence of cover crops which together mitigate disturbances and improve the soil organic matter content (Table 2) and microclimatic conditions at the soil surface (Chan 2001; Blanchart et al. 2006). Moreover, the cover crop presence could also have increased soil biota abundance through additional litter inputs and root exudates supply through the rhizosphere (Blanchart et al. 2006). In contrast, the organic system studied here did not receive regular organic amendments. This could explain the relatively low $\mathrm{C}$ and $\mathrm{N}$ contents and the slower restoration of soil biota in this system
(Table 2 and Fig. 2). However, in our study, the organic system has benefited of the "legume green manure" effect induced by 2 years of continuous alfalfa cropping and whose residues have been incorporated into the soil at the sampling year. The absence of insecticide treatment in the organic systems and in the conservation (for 9 years) may explain the increase of macrofauna (Bunemann et al. 2006). Concerning herbicides and mineral fertilizers, Wardle (1995) and Bunemann et al. (2006) reported limited direct effect on soil biota but mainly indirect effect such as alterations of the plant community composition, litter quality, and soil abiotic conditions (Bardgett and McAlister 1999; Wardle et al. 2001). Interestingly, we observed here a higher enhancement effect of the conservation than the organic system on soil biota despite of herbicide and mineral fertilizer use in the conservation system and their exclusion in the organic system. The absence of negative effect of herbicide and fertilizers on soil biota is in contrast with Birkhofer et al. (2008a) who showed a strong detrimental impact of their application on soil biota. Overall, our study suggests that, after 14 years of cropping system differentiation, long-term no-tillage associated with cover crop use has greater enhancement potential for soil biota than periodic legume green manure use and pesticide and mineral fertilizer prohibition. Tillage also appears as a major factor explaining differential response of soil organism groups to conservation versus conventional tillage systems (Kladivko 2001).

3.2 Differential response of soil organism groups to alternative cropping systems

Our study showed that, for both alternative cropping systems, the enhancement effect on the abundance and/or biomass of soil organism groups was higher for nematodes and macrofauna than for microorganisms (Fig. 2). The same pattern was already observed by Postma-Blaauw et al. (2010) for the response of these soil organism groups to agricultural intensification. Reviewing the impact of tillage on the soil food web, Wardle (1995) found that the tillage response of organisms associated with microscopic soil pores (microorganisms and microfauna) was weaker than that of larger size organisms (meso- and macrofauna). Indeed, larger organisms are more prone to physical disruption, abrasion, and habitat alterations by tillage practices. In contrast, smaller organisms are probably mainly affected by litter location and soil abiotic condition alterations, e.g., soil physicochemical conditions and soil organic matter status. This is in accordance with our observations for macroinvertebrates but not for nematodes. Wardle (1995) pointed to more extreme responses of nematodes, either positively or negatively, compared to microorganisms, which resulted in a weak negative overall response to tillage. This could be explained by their trophic interactions as microorganisms exert a bottom-up control on microbivorous 
Fig. 2 Index $V$ (representing the level of response to alternative cropping systems versus conventional cropping system) of the abundance of different taxonomic and functional groups of soil biota (mean $\pm 95 \%$ confidence interval). Green and orange represent conservation versus conventional cropping system and organic versus conventional cropping system, respectively. Circles and triangles represent density and biomass, respectively. Both alternative cropping systems increase the abundance of most taxonomic and functional groups of soil biota. The response was stronger for macrofauna and nematodes than for microorganisms. The overall enhancement effect was stronger for the conservation agriculture system than for the organic farming system

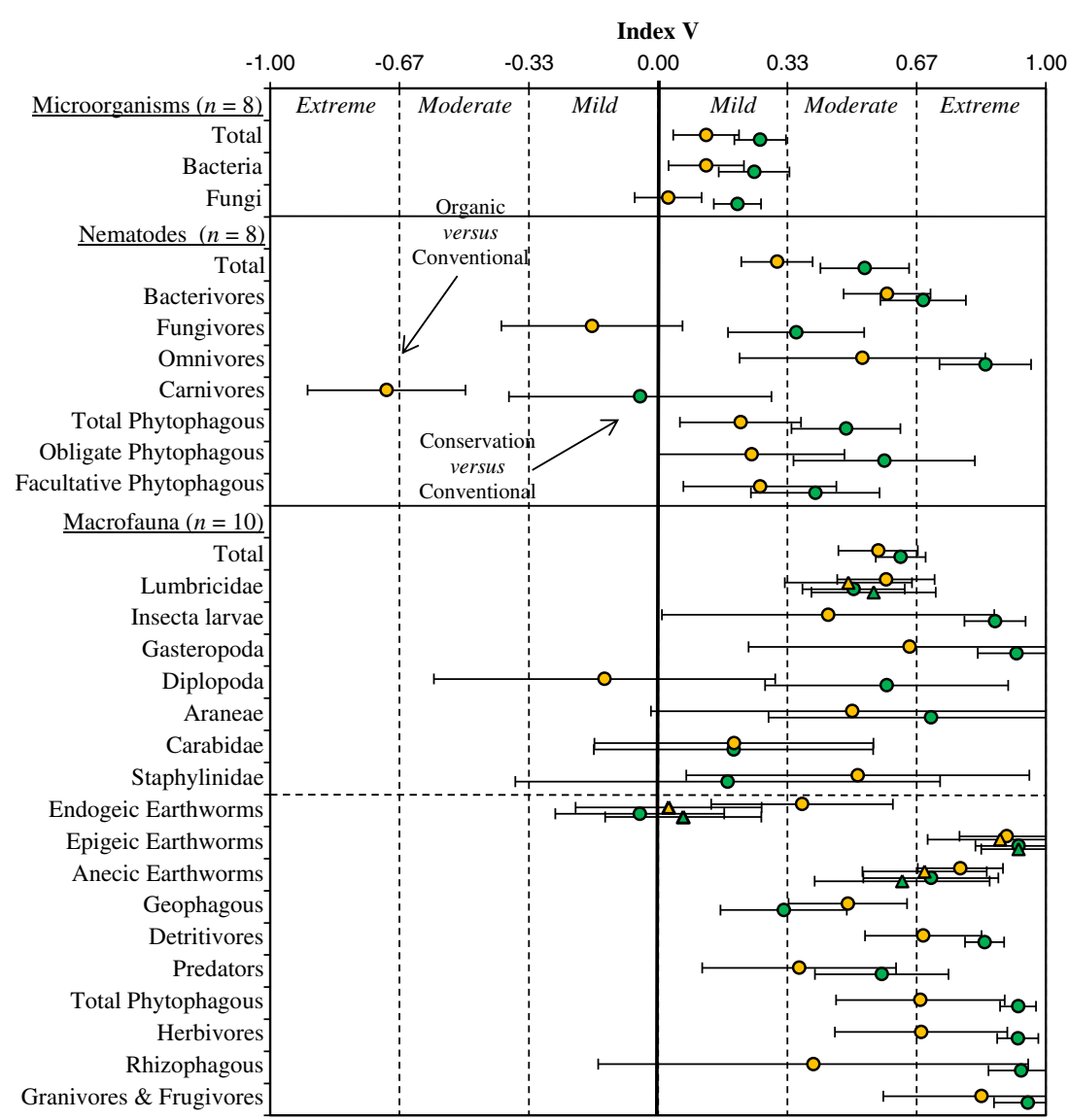

nematodes, and conversely microbivorous nematodes exert a top-down regulation of microorganisms. Hence, microbial biomass alteration by tillage flows to microbivorous nematodes through their grazing pressure adjustment. Regarding macroinvertebrates at higher trophic level of the soil food web, tillage induced different processes that probably contribute to their stronger response: direct mortality, bottom-up control through reduced food availability at lower trophic levels, and top-down control through higher exposure to predation (e.g., by birds). Within the macrofauna group, belowground organisms (e.g., earthworms and insect larvae) are likely more sensitive to physical damages than aboveground invertebrates (e.g., millipedes, beetles, and spiders) that are more mobile and could reinvade the plot by migration from nearby undisturbed areas (Robertson et al. 1994; Kladivko 2001). In contrast, habitat and microclimatic condition improvement and higher food availability in no-tillage systems are of likely greater significance for these aboveground invertebrates (Blanchart et al. 2006). Similarly, despite tillage which occurs in the organic cropping system, the legume green manure incorporation may have provided high-quality food for macroinvertebrates, especially for endogeic earthworms, and fostered the bacterial pathway of the soil food web (Mäder et al. 2002). Insecticide prohibition may also have participated to the stronger responses of macroinvertebrates in both alternative cropping systems.

\subsection{Alternative cropping systems effect among functional groups of the soil food web and implications for soil functioning}

Our study showed important differences of the soil food web structure between the cropping systems. Regarding the soil micro-food web, the conservation system enhanced both bacteria and fungi compared with the conventional system (Fig. 3). Interestingly, no shift in fungal/bacterial ratio was found between cropping systems (Table 2). This is in accordance with recent studies (e.g., Helgason et al. 2009), highlighting that the assumption that no-tillage would result in fungal-dominated system (Hendrix et al. 1986; Frey et al. 1999) may be limited to the litter layer. The organic system significantly increased bacteria $\left(1.35 \times 10^{10}\right.$ and $1.04 \times 10^{10}$ gene copy $\mathrm{g}^{-1}$ soil in the organic and conventional systems, respectively) and not fungi $\left(3.48 \times 10^{8}\right.$ and $3.38 \times 10^{8}$ gene copy $\mathrm{g}^{-1}$ soil, respectively) (Fig. $2 \mathrm{a}$ ). Indeed, the incorporation of the low $C / N$ alfalfa residues in this system seems to have induced a fast and likely short-term enhancement of bacteria. This is confirmed by the higher proportion of opportunistic 
Fig. 3 Abundance of the main taxonomic and functional groups of the soil micro-food web (microbial and nematode communities only) in the three cropping systems (mean \pm standard error, $n=8$ ). Different letters indicate significant Tukey's HSD differences between cropping systems at $\alpha=5 \%$.***,**, *, and ns indicate $p<0.001, p<0.01$, $p<0.05$, and $p>0.05$, respectively. The conservation system increased both the bacterial and fungal pathways of the soil micro-food web while the organic system increased only the bacterial pathways. The response was stronger for microbivorous nematodes than for microorganisms. The conservation system altered the structure of the bacterial community compared with the organic and the conventional systems

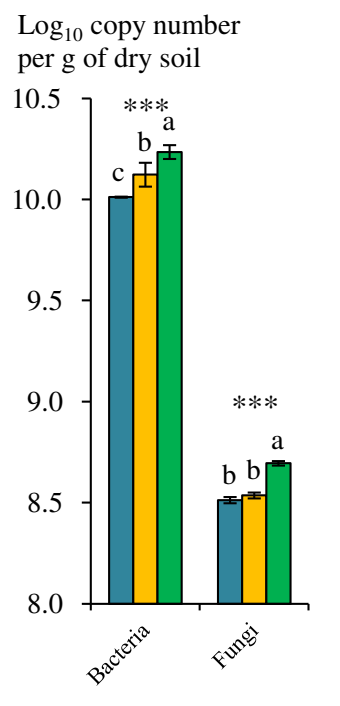

$\%$ of $16 \mathrm{~S}$ rRNA gene copies

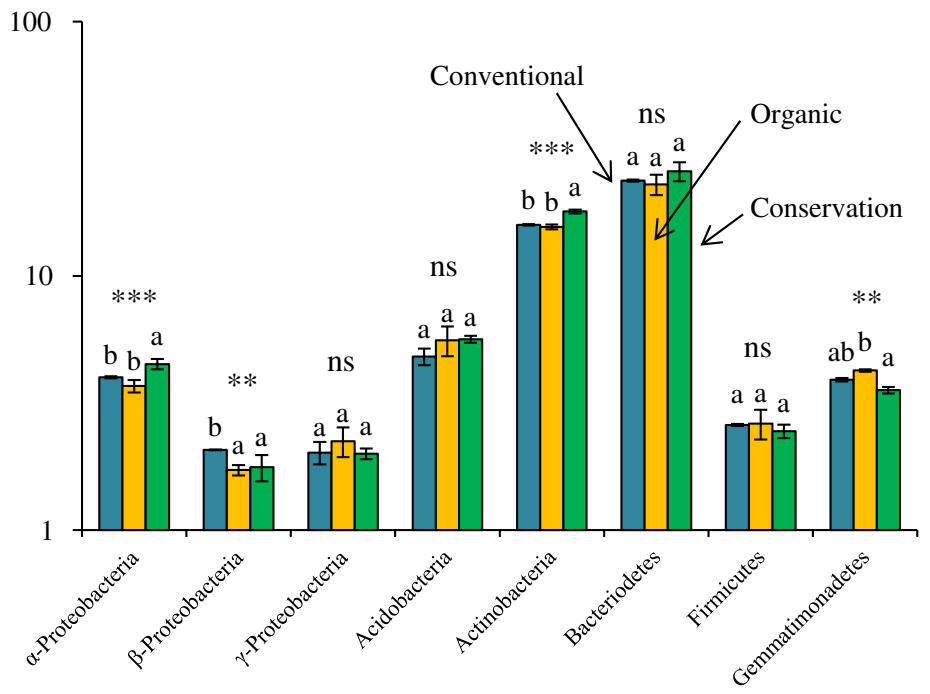

Individuals per $100 \mathrm{~g}$ of dry soil

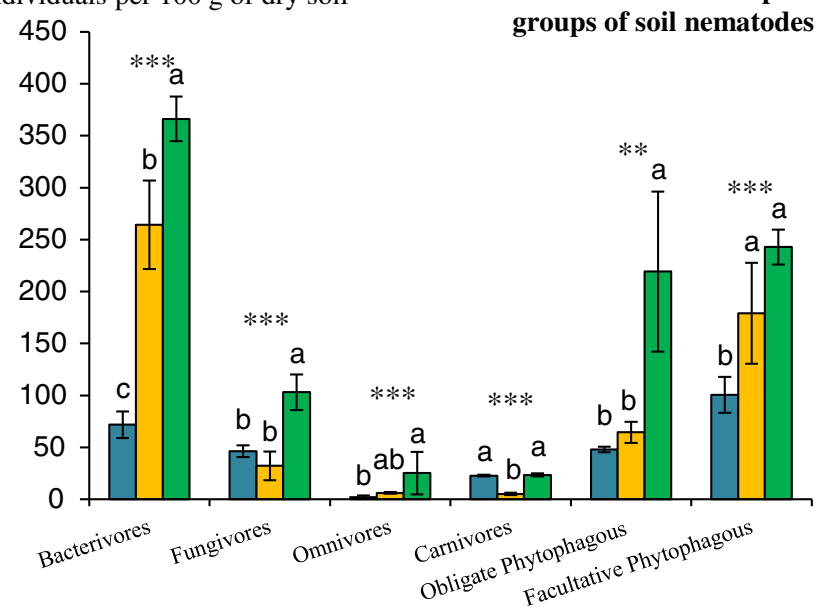

Abundance of bacteria, fungi and relative abundance of the main bacterial taxa
100

Abundance of the main trophic groups of soil nematodes Eacultutio bacteria-feeding nematodes which resulted in a higher enrichment index ( 84.6 and 68.5 in organic and conventional systems, respectively) (Table 2).

Regarding the bacterial community, $\alpha$-Proteobacteria and Actinobacteria were stimulated in the conservation system, whereas the conventional and the organic system presented higher relative abundance of $\beta$-Proteobacteria and $\gamma$ Proteobacteria (though not significant), respectively (Fig. 3). Investigating the taxonomic composition of in situ bacterial community colonizing crop residues, Pascault et al. (2010) found that $\alpha$-Proteobacteria and Actinobacteria were stimulated on residues left on soil surface, whereas the incorporation of the residues induced a stimulation of $\gamma$-Proteobacteria. Hence, crop residue location was likely a major factor of bacterial community structure differentiation between our cropping systems. $\beta$-Proteobacteria and $\gamma$-Proteobacteria have been previously described as copiotrophs (fast-growing r-strategist) (Fierer et al. 2007) and early colonizers of crop residues (Bernard et al. 2007). This is in accordance with the higher RNA/DNA ratio in the conventional and the organic system (Table 2) that suggested smaller but proportionally more active microbial communities in systems with conventional tillage. This could also be associated with greater microbial energy use inefficiency due to greater disturbance induced by tillage (Wardle 1995).

Microbivorous nematodes followed the same pattern of response to the cropping systems than that of microorganisms, but the differences were much more contrasted, probably mainly due to their trophic interactions (Fig. 3).

This suggests that microbial growth improvement by alternative cropping systems may be far beyond the observed patterns of abundance improvement as the grazing pressure on microorganisms was probably more intense in the alternative cropping systems. It also suggests that bacterial and fungal turnover could be more important in the conservation and in the organic system (for bacteria only) compared to the 
Fig. 4 Density of the main trophic groups of soil macroinvertebrates, of the taxonomic groups of soil and litter dwelling macroinvertebrates, and of the density and biomass of total earthworm (Lumbricidae) community and their three ecological groups in the three cropping systems (mean \pm standard error, $n=10$ ). Different letters indicate significant Tukey's HSD differences between cropping systems at $\alpha=$ $5 \%$. ***, $* *, *$, and ns indicate $p<0.001, p<0.01, p<0.05$, and $p>0.05$, respectively. The conservation system highly increased the abundance and biomass of most taxonomic and functional groups of soil macroinvertebrates. The increase with organic system was lower except for earthworm abundance and biomass and staphylinid beetles

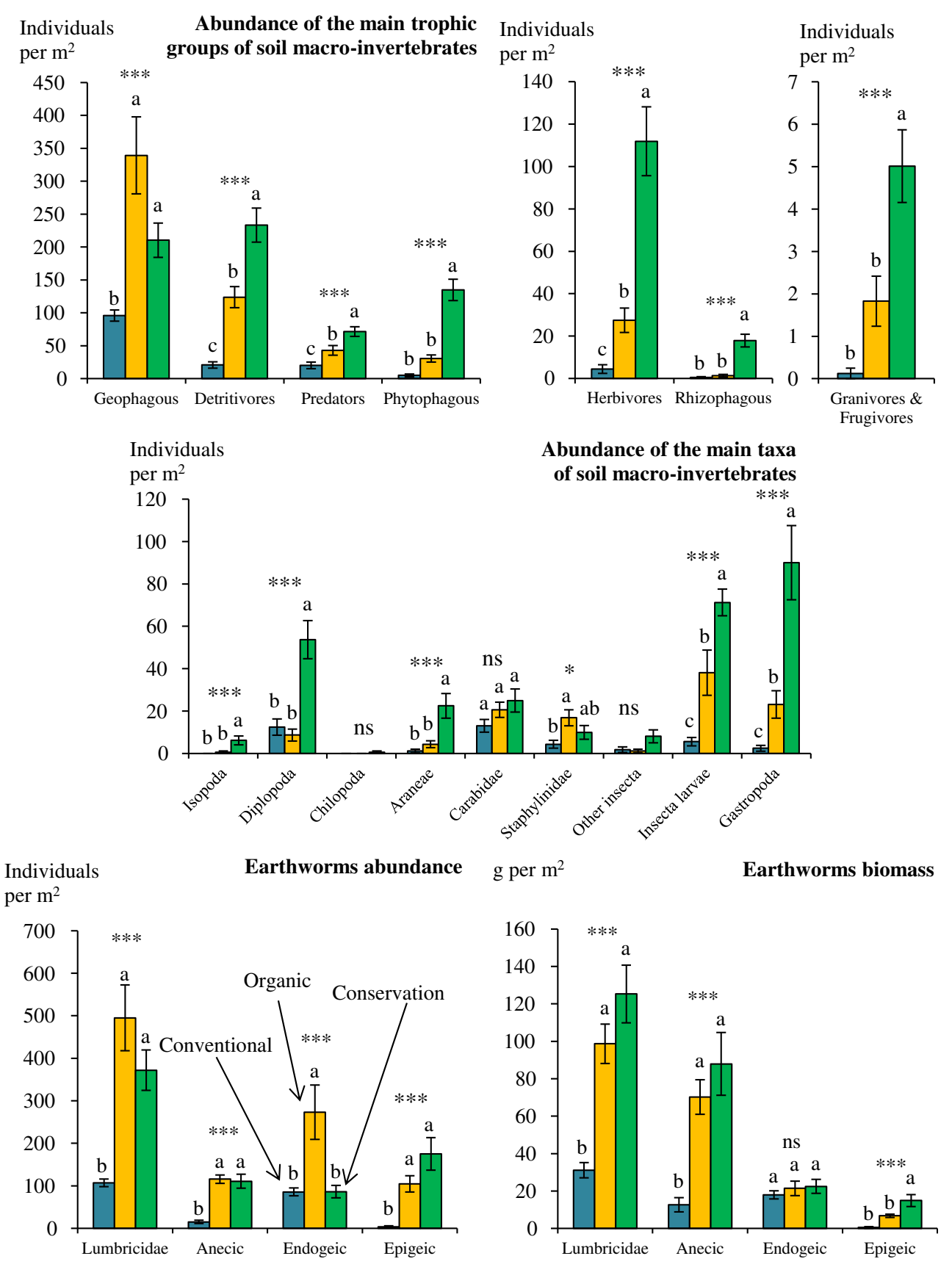

conventional system. This is even more pronounced for bacteria associated with bacteria-feeding nematodes. This is in accordance with Wardle (1995) who pointed higher microbivorous nematodes grazing pressure on bacteria than on fungi. This highlights the interest to study microorganisms and their regulators in a trophic interaction perspective. Furthermore, higher abundance of higher trophic level nematodes, i.e., omnivores and carnivores, in the conservation system suggests that the enhancement effect propagates further along the soil food web in what is called a trophic cascade, i.e., changes in organic resource may cascade up the food chain to affect even higher trophic levels. Moreover, these nematodes are known for their high sensitivity to disturbance and stress factor (Bongers and Bongers 1998). As they are K-strategists, they may take longer to recover after a perturbation than do the opportunistic nematodes. Their higher abundance in the conservation system than in the organic system recently plowed, which resulted in higher maturity and structure index (Table 2), highlighted more stable and less disturbed environmental conditions in the conservation system. Further, the fact that the conventional system has not been plowed at the sampling year may possibly explain the high abundance of predaceous nematodes and conversely the low abundance of microbivorous nematodes in this 


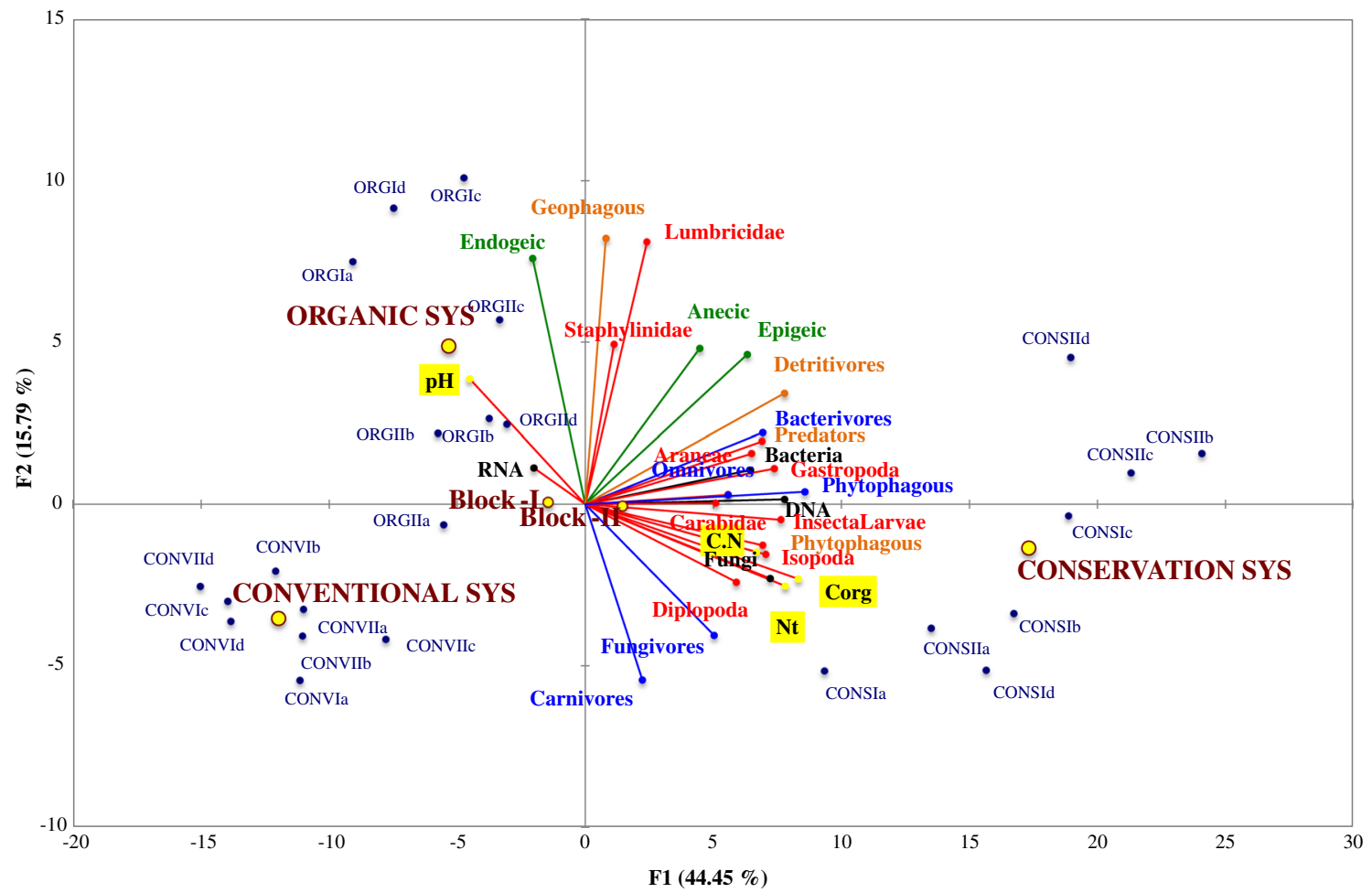

Fig. 5 Biplot representation of the principal component analysis (PCA) performed on abiotic and biotic parameters of 24 soils sampled in 3 agricultural systems and 2 replication blocks for which gravity centers are shown. The correlation circle of variables has been superposed to the PCA plot, where abiotic variables were underlined in yellow $\left(\mathrm{pH}, C_{\mathrm{org}}\right.$, $N_{\text {tot }}, C / N$ ), microbial parameters appear in black (DNA, RNA, bacteria, fungi), nematofauna trophic guilds in blue (bacterivores, omnivores, fungivores, carnivores, phytophagous), earthworm categories in green

system. This may have had consequences for microbial turnover, particularly for bacteria, due to trophic cascade.

The conservation system showed higher abundance of detritivorous macroinvertebrates, i.e., litter transformers, including millipedes (i.e., Diplopoda), woodlice (i.e., Isopoda), and epigeic and anecic earthworms (Fig. 4). This was likely due to the presence of an abundant litter mulch at the soil surface, and the absence of tillage whose impact on anecic earthworms has been largely documented (e.g., Chan 2001).

The organic system also enhanced the abundance and biomass of anecic and epigeic earthworms and the abundance of endogeic earthworms, though this did not result in biomass differences (Fig. 4). These results are in accordance with the previous observations of Pelosi et al. (2009a) on the same trial for the conservation system but not for the organic system. However, although plowing occurred in the organic system, incorporating a significant amount of high-quality food alfalfa residues into the soil could have allowed a quick recovery of endogeic and to a lower extent of anecic earthworms (Boström 1995). This recovery may possibly be short-term only as the organic system is regularly plowed. Altogether, these patterns suggest that the long-term improvement of the soil food web in the conservation agriculture system might promote higher (epigeic, endogeic, anecic), macrofauna taxa in red (Lumbricidae, Staphylinidae, Araneae, Gastropoda, Carabidae, insect larvae, Isopoda, Diplopoda), and macrofauna functional groups in orange (geophagous, detritivores, predators, phytophagous). This figure clearly shows that most of the abiotic variables (except $\mathrm{pH}$ ) and the biotic variables (except RNA and endogeic earthworms) are mainly increased in conservation system

soil fertility through improved nutrient cycling and conservation (House and Brust 1989). Moreover, enhanced bacterial pathway in the organic system suggests that legume green manure may also promote short-term improvement of soil fertility. Finally, the enhancement of anecic earthworms in the conservation system may help to substitute soil tillage through their burrowing and casting activities.

The conservation system showed higher abundance of phytophagous biota, including obligate phytophagous nematodes and herbivores, mainly slugs (i.e., Gastropoda), and rhizophagous, mainly dipterous larvae, macroinvertebrates (Figs. 3 and 4). This is likely due to the presence of the cover crop. As some of these phytophagous organisms are likely crop pests, this could threaten crop productivity. However, both alternative cropping systems showed higher abundance of top predators, including mainly staphylinid beetles in the organic system and predatory nematodes, carabid beetles, and spiders in the conservation system (Fig. 4). They may have been enhanced by bottom-up control through the enhancement of the soil food web (Birkhofer et al. 2008b), by improved habitat conditions provided by cover crop and mulch in the conservation system, and possibly by higher weed density (Dielh et al. 2012). Higher abundance of natural 
enemies may therefore help to keep in check pest through topdown control (Straub et al. 2008). Although the enhancement of ground beetle abundance (i.e., Carabidae) by alternative cropping systems was not substantial (Fig. 4), the abundance of their larvae was higher in the conservation system $(71,30$, and 6 ind. $\mathrm{m}^{-2}$ in the conservation, organic, and conventional systems, respectively). Further, the functional diversity of the community was highly improved and included higher abundance of frugivores and granivores species in the conservation system (Fig. 4). This may result in higher weed seed predation (Menalled et al. 2007). Therefore, our study suggests that alternative cropping systems and the conservation system especially may rely more efficiently on biological control for pest and weed management (Altieri 1999; House and Brust 1989; Straub et al. 2008).

The PCA realized both on abiotic and biotic parameters shows correlations between these parameters (Fig. 5). The first axis separates the conservation systems from conventional and organic systems. This reinforces the result that the conservation system is more efficient than the organic system (in our context) to restore almost all groups of soil biota; only endogeic earthworms and the quantity of RNA are opposite to conservation system and especially related to the organic system.

\section{Conclusion}

Long-term conservation and organic alternative cropping systems improved the abundance and/or biomass of soil biota and altered the structure of the soil food web compared to a conventional system. Our study showed that the enhancement effect on the overall soil biota can be stronger for conservation agriculture than for organic farming. This could however be context-dependent. Here, we suspect that the conservation system has resulted in long-term soil biota enhancement, whereas this enhancement was probably mainly short-term in the organic farming system as it does not receive regular organic amendments but likely has benefited from recent legume green manure incorporation. Altogether, our study suggests that long-term no-tillage associated with cover crop use has greater enhancement potential for soil biota than periodic legume green manure use and pesticide and mineral fertilizer prohibition. It is interesting to note that yields are also slightly higher under conservation management compared to organic farming even if the causal relationship between biodiversity and yield is not obvious. Further research studies are needed to assess if the higher enhancement potential of conservation agriculture versus organic farming on soil biota is consistent whatever the diversity of cropping systems that could be involved within each of these alternative farming systems. We emphasize that cropping systems should be compared cautiously and that a holistic and comprehensive consideration of agricultural practices composing the cropping systems of each farming system, which could vary depending on local context, is necessary.

Finally, our study suggests that alternative farming systems, and conservation agriculture especially, can foster soil quality through an increase in the diversity and abundance of functional groups (Kibblewhite et al. 2008). This could result in improved soil fertility and higher biological control potential for pest and weed management. However, soil biota showed complex responses to agricultural practices according to the functional groups or trophic levels considered. This means that managing soil quality to achieve sustainable agricultural production along with the provision of other ecosystem services requires greater knowledge on the biotic interactions occurring in soil and their linkages with agroecosystem functioning.

Acknowledgments This study was financially supported by the ANR Systerra-PEPITES research program coordinated by Dr. S. de Tourdonnet (IRC-Montpellier SupAgro). We greatly thank O. Ba, J. Thénard, C. Marraud, J.P. Pétraud, N. Cheviron, E. Kouakoua, L. Amenc, E. Tournier, A. Martin, D. Viratel, R. Lefèvre, C. Naisse, and S. Lutfalla for laboratory, technical, and field support. We are also grateful to A. Marmeys, G. Grandeau, and Dr. J.F. Vian for valuable discussions and P. Deleporte, A. Gauffreteau, and Dr. C. Salomé for their advice on statistical issues.

\section{References}

Altieri MA (1999) The ecological role of biodiversity in agroecosystems. Agric Ecosyst Environ 74(1-3):19-31. doi:10.1016/s01678809(99)00028-6

Bardgett RD, McAlister E (1999) The measurement of soil fungal:bacterial biomass ratios as an indicator of ecosystem self-regulation in temperate meadow grasslands. Biol Fertil Soils 29(3):282-290. doi: $10.1007 / \mathrm{s} 003740050554$

Bengtsson J, Ahnstrom J, Weibull AC (2005) The effects of organic agriculture on biodiversity and abundance: a meta-analysis. J Appl Ecol 42(2):261-269. doi:10.1111/j.1365-2664.2005.01005.x

Bernard L, Mougel C, Maron PA, Nowak V, Leveque J, Henault C, Haichar FEZ, Berge O, Marol C, Balesdent J, Gibiat F, Lemanceau P, Ranjard L (2007) Dynamics and identification of soil microbial populations actively assimilating carbon from C-13-labelled wheat residue as estimated by DNA- and RNA-SIP techniques. Environ Microbiol 9(3):752-764. doi:10.1111/j.1462-2920. 2006.01197.x

Birkhofer K, Bezemer TM, Bloem J et al (2008a) Long-term organic farming fosters below and aboveground biota: implications for soil quality, biological control and productivity. Soil Biol Biochem 40(9):2297-2308. doi:10.1016/j.soilbio.2008.05.007

Birkhofer K, Wise DH, Scheu S (2008b) Subsidy from the detrital food web, but not microhabitat complexity, affects the role of generalist predators in an aboveground herbivore food web. Oikos 117:494 500. doi:10.1111/j.0030-1299.2008.16361.x

Blanchart E, Villenave C, Viallatoux A, Barthes B, Girardin C, Azontonde A, Feller C (2006) Long-term effect of a legume cover crop (Mucuna pruriens var. utilis) on the communities of soil macrofauna and nematofauna, under maize cultivation, in southern Benin. Eur J Soil Biol 42:S136-S144. doi:10.1016/j.ejsobi.2006.07.018 
Bommarco R, Kleijn D, Potts SG (2012) Ecological intensification: harnessing ecosystem services for food security. Trends Ecol Evol 28(4):230-238. doi:10.1016/j.tree.2012.10.012

Bongers T (1990) The maturity index: an ecological measure of environmental disturbance based on nematode species composition. Oecologia 83:14-19. doi:10.1007/BF00324627

Bongers T, Bongers M (1998) Functional diversity of nematodes. Appl Soil Ecol 10(3):239-251. doi:10.1016/s0929-1393(98)00123-1

Boström U (1995) Earthworm populations (Lumbricidae) in ploughed and undisturbed leys. Soil Tillage Res 35(3):125-133. doi:10.1016/ 0167-1987(95)00489-0

Bouché MB, Gardner RH (1984) Earthworm functions. VII. Population estimation techniques. Rev Ecol Biol Sols 21:37-63

Bunemann EK, Schwenke GD, Van Zwieten L (2006) Impact of agricultural inputs on soil organisms - a review. Aust J Soil Res 44(4):379 406. doi:10.1071/sr05125

Chan KY (2001) An overview of some tillage impacts on earthworm population abundance and diversity - implications for functioning in soils. Soil Tillage Res 57(4):179-191. doi:10.1016/s01671987(00)00173-2

De Vries FT, Thébault E, Liiri M, Birkhofer K, Tsiafouli MA, Bjornlund L, Jorgensen HB, Brady MV, Christensen S, de Ruiter PC, d'Hertefeldt T, Frouz J, Hedlund K, Hemerik L, Gera Hol WH, Hotes S, Mortimer SR, Setälä H, Sgardelis SP, Uteseny K, van der Putten WH, Wolters V, Bardgett RD (2013) Soil food web properties explain ecosystem services across European land use systems. PNAS. doi:10.1073/pnas.1305198110

Debaeke P, Munier-Jolain N, Bertrand M, Guichard L, Nolot JM, Faloya V, Saulas P (2009) Iterative design and evaluation of rule-based cropping systems: methodologies and case-studies. A review. Agron Sustain Dev 29:73-86. doi:10.1007/978-90-481-2666-8 43

Diehl E, Wolters V, Birkhofer K (2012) Arable weeds in organically managed wheat fields foster carabid beetles by resource- and structure-mediated effects. Arthropod-Plant Interactions 6:75-82. doi:10.1007/s11829-011-9153-4

DuPont ST, Ferris H, van Horn H (2009) Effects of cover crop quality and quantity on nematode-based soil food webs and nutrient cycling. Appl Soil Ecol 41:157-167

Ferris H, Bongers T, de Goede RGM (2001) A framework for soil food web diagnostics: extension of the nematode faunal analysis concept. Appl Soil Ecol 18(1):13-29. doi:10.1016/s0929-1393(01)00152-4

Fierer N, Jackson JA, Vilgalys R, Jackson RB (2005) Assessment of soil microbial community structure by use of taxon-specific quantitative PCR assays. Appl Environ Microbiol 71(7):4117-4120. doi:10. 1128/aem.71.7.4117-4120.2005

Fierer N, Bradford MA, Jackson RB (2007) Toward an ecological classification of soil bacteria. Ecology 88(6):1354-1364. doi:10.1890/05-1839

Frey SD, Elliott ET, Paustian K (1999) Bacterial and fungal abundance and biomass in conventional and no-tillage agroecosystems along two climatic gradients. Soil Biol Biochem 31(4):573-585. doi:10. 1016/s0038-0717(98)00161-8

Helgason BL, Walley FL, Germida JJ (2009) Fungal and bacterial abundance in long-term no-till and intensive-till soils of the Northern Great Plains. Soil Sci Soc Am J 73(1):120-127. doi:10.2136/sssaj2007.0392

Hendrix PF, Parmelee RW, Crossley DA, Coleman DC, Odum EP, Groffman PM (1986) Detritus food webs in conventional and no-tillage agroecosystems. Bioscience 36(6):374-380. doi:10.2307/1310259

Hole DG, Perkins AJ, Wilson JD, Alexander IH, Grice F, Evans AD (2005) Does organic farming benefit biodiversity? Biol Conserv 122:113-130. doi:10.1016/j.biocon.2004.07.018

House GJ, Brust GE (1989) Ecology of low-input, no-tillage agroecosystems. Agric Ecosyst Environ 27(1-4):331-345. doi:10. 1016/0167-8809(89)90096-0

ISO 23611-4 (2007) Soil quality—sampling of soil invertebratespart 4: sampling, extraction and identification of soilinhabiting nematodes
Kibblewhite MG, Ritz K, Swift MJ (2008) Soil health in agricultural systems. Philos Trans R Soc B-Biol Sci 363(1492):685-701

Kladivko EJ (2001) Tillage systems and soil ecology. Soil Tillage Res 61: $61-76$

Mäder P, Fliessbach A, Dubois D, Gunst L, Fried P, Niggli U (2002) Soil fertility and biodiversity in organic farming. Science 296:1694 1697. doi:10.1126/science. 1071148

Marasas ME, Sarandon SJ, Cicchino AC (2001) Changes in soil arthropod functional group in a wheat crop under conventional and notillage systems in Argentina. Appl Soil Ecol 18:61-68. doi:10.1016/ S0929-1393(01)00148-2

Menalled FD, Smith RG, Dauer JT, Fox TB (2007) Impact of agricultural management on carabid communities and weed seed predation. Agric Ecosyst Environ 118(1-4):49-54. doi:10.1016/j.agee.2006.04.011

Mühling M, Woolven-Allen, Murrell JC, Joint I (2008) Improved groupspecific PCR primers for denaturating gradient gel electrophoresis analysis of the genetic diversity of complex microbial community. Int Soc Microb Ecol 2:379-392

Pascault N, Nicolardot B, Bastian F, Thiebeau P, Ranjard L, Maron PA (2010) In situ dynamics and spatial heterogeneity of soil bacterial communities under different crop residue management. Microb Ecol 60(2):291-303. doi:10.1007/s00248-010-9648-z

Pelosi C, Bertrand M, Roger-Estrade J (2009a) Earthworm community in conventional, organic and direct seeding with living mulch cropping systems. Agron Sustain Dev 29(2):287-295. doi:10.1051/agro/2008069

Pelosi C, Bertrand M, Capowiez Y, Boizard H, Roger-Estrade J (2009b) Earthworm collection from agricultural fields: Comparisons of selected expellants in presence/absence of hand-sorting. Eur J Soil Biol 45:176-183. doi:10.1016/j.ejsobi.2008.09.013

Philippot L, Bru D, Saby NPA, Cuhel J, Arrouays D, Simek M, Hallin S (2009) Spatial patterns of bacterial taxa in nature reflect ecological traits of deep branches of the 16S rRNA bacterial tree. Environ Microb 11:1096-1104

Philippot L, Andersson SGE, Battin TJ, Prosser JI, Schimel JP, Whitman WB, Hallin S (2010) The ecological coherence of high bacterial taxonomic ranks. Nat Rev Microbiol 8(7):523-529. doi:10.1038/ nrmicro2367

Postma-Blaauw MB, de Goede RGM, Bloem J, Faber JH, Brussaard L (2010) Soil biota community structure and abundance under agricultural intensification and extensification. Ecology 91(2):460-473. doi:10.1890/09-0666.1

Robertson LN, Kettle BA, Simpson GB (1994) The influence of tillage practices on soil macrofauna in a semi-arid agroecosystem in northeastern Australia. Agric Ecosys Environ 48(2):149-156

Straub CS, Finke DL, Snyder WE (2008) Are the conservation of natural enemy biodiversity and biological control compatible goals? Biol Control 45(2):225-237. doi:10.1016/j.biocontrol.2007.05.013

Tilman D, Cassman KG, Matson PA, Naylor R, Polasky S (2002) Agricultural sustainability and intensive production practices. Nature 418(6898):671-677. doi:10.1038/nature01014

Vainio EJ, Hantula J (2000) Direct analysis of wood-inhabiting fungi using denaturating gel electrophoresis of amplified ribosomal DNA. Mycol Res 104:927-936

Vandermeer J (1995) The ecological basis of alternative agriculture. Annual review of Ecology, Evolution, and Systematics 26 (201-224)

Wardle DA (1995) Impacts of disturbance on detritus food webs in agroecosystems of contrasting tillage and weed management practices. In: Begon M, Fitter AH (eds) Advances in ecological research, vol 26. Academic Press, pp 105-185. doi:10.1016/s0065-2504(08)60065-3

Wardle DA, Yeates GW, Bonner KI, Nicholson KS, Watson RN (2001) Impacts of ground vegetation management strategies in a kiwifruit orchard on the composition and functioning of the soil biota. Soil Biol Biochem 33(7-8):893-905. doi:10.1016/s0038-0717(00)00235-2

Yeates GW, Bongers T, Degoede RGM, Freckman DW, Georgieva SS (1993) Feeding habits in soil nematode families and genera - an outline for soil ecologists. J Nematol 25(3):315-331 